\begin{tabular}{|l||}
\hline Encyclopedia of Entomology \\
\hline \hline Springer Science+Business Media B.V. 2008 \\
\hline \hline 10.1007/978-1-4020-6359-6_4491 \\
\hline \hline John L. Capinera \\
\hline
\end{tabular}

\title{
Sweetpotato Flea Beetle, Chaetocnema confinis (Coleoptera: Chrysomelidae: Alticinae)
}

\section{Pierre Jolivet $^{2}$}

(2) Paris, France

\section{Without Abstract}

Chaetocnema (Tlanoma) confinis Crotch, 1873 is a very small (1.4-1.8 mm) and light species. Although thought to have originated in North America (USA), it has become ubiquitous in the tropics of the Old and New World. It is becoming the most widely spread species of leaf-beetle. It has two known synonyms: $C$. flavicornis J. LeConte and C. etiennei Jolivet. Chaetocnema perplexa Blake from Central America is probably also a junior synonym.

\section{Morphology}

Chaetocnema confinis is a very small species; even the female is ált; $2 \mathrm{~mm}$. The adult is black to dark bronze, moderately glossy, with the antennae pale brown, the ventral surface black to dark brown, the femora brown to dark brown, the tibiae brown to pale brown, the tarsi pale brown. The striae on the elytra are parallel and the punctures moderate. The punctures are deep on the pronotum (Fig. 158). 


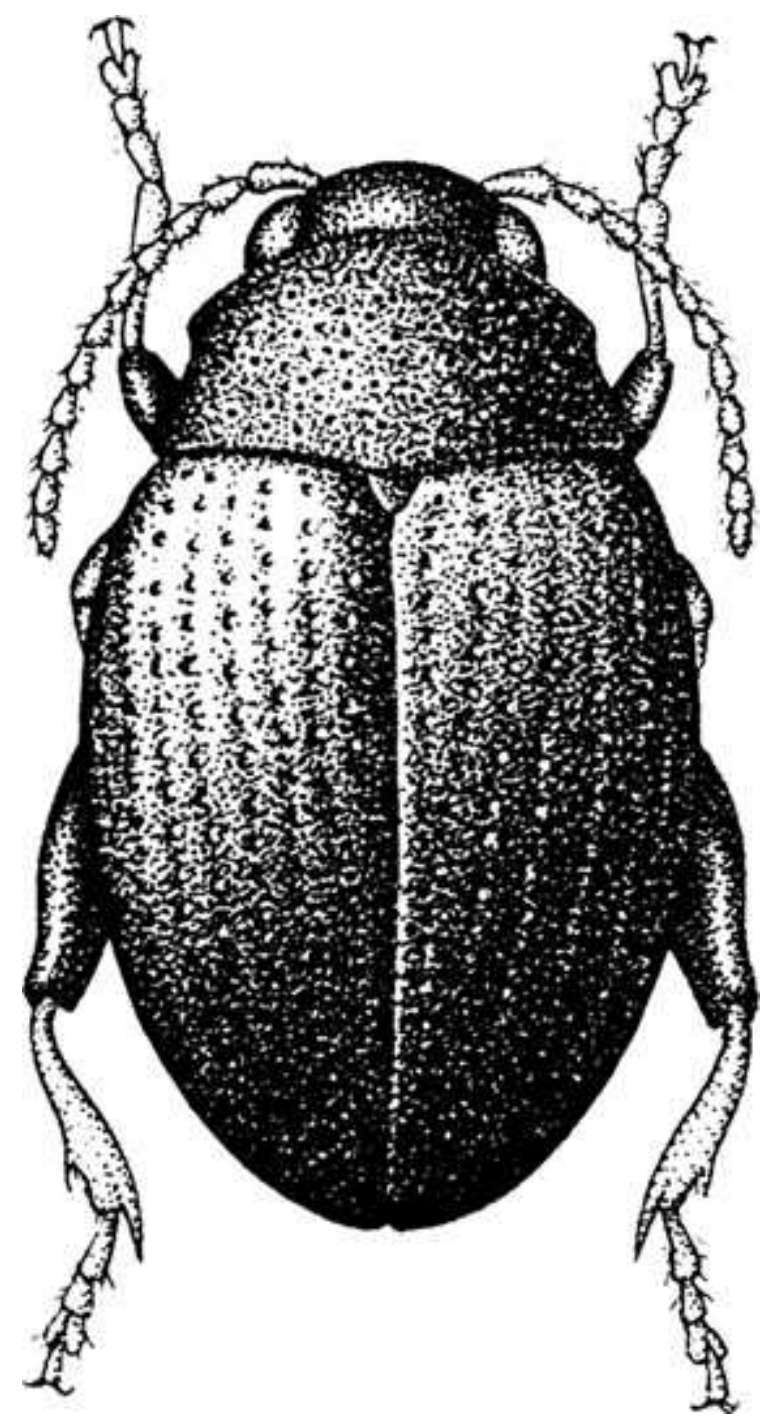

Sweetpotato Flea Beetle, Chaetocnema confinis (Coleoptera: Chrysomelidae: Alticinae), Figure 158 Chaetocnema confinis Crotch.

The male has the fore and middle tarsus with the first segment somewhat enlarged. The aedeagus relatively small and sinuate. Chaetocnema perplexa Blake seems to differ by only a small variation of the shape of the aedeagus. The eggs are deposited in small groups and do not differ from those of related species $(0.8 \times 0.2 \mathrm{~mm})$. The larvae are eruciform, straight, cylindrical, legged and measure $6 \mathrm{~mm}$ at the final stage. They live on plant roots.

\section{Biology}

Normally, C. confinis larvae feed inside Convolvulaceae roots, but they also attack the collar at the limit between stem and root. Long narrow grooves are eaten in the leaves, especially on the upper surface along the veins, during May and early June in North America, and throughout the year in the tropics. When these channels are numerous, the leaf may wilt. In the tropics there are many generations per year and no winter diapause. Otherwise in the US 
the species is univoltine.

In the US, $C$. confinis overwinters as adult under trash and various sheltered places. When they come out of hibernation, adults attack the plants when they are set out from seedbeds. By the end of June, they leave the sweet potatoes, migrating to bindweed where they lay their eggs and die. The larvae hatch after 3 weeks incubation. The new generation of beetles will feed and enter diapause in the fall. In the US and Canada, both sexes are present. In the Old World tropics only thelytokous parthenogenetic females are present, and so far as is known this is the condition in Central and South America.

\section{Distribution}

Chaetocnoma confinis originated in the US and Canada where both sexes are present. The beetle walks, flies and jump easily. Its recent dispersal in Africa and Asia-Pacific is probably due to typhoons and hurricanes because the beetle is light, small and winged. The first specimen was discovered on Ipomoea aquatica, a vegetable grown in Reunion, in 1976. It was then described under the name of $C$. etiennei Jolivet and 10 years later M. L. Cox synonymized it with $C$. confinis. Having only females in the tropics makes identification rather difficult.

Then the beetle invaded Madagascar, Mauritius and spread over most of tropical and southern Africa. C. confinis is also known from Brazil and Galapagos, Central America, Oceania (Palau), New Caledonia, Asia (India, Vietnam, Thailand, Ryukyu islands, etc.). At the speed that it spreads, New Guinea, Indonesia and Australia are the next targets. It is very probable that the species is already in New Guinea and several Indonesian islands. Probably it will soon cover all the tropical lands of Indian Ocean and Pacific.

\section{Food Plants}

The beetle feeds on Convolvulaceae. It feeds on Convolvulus arvensis (bindweed) in the US and Canada, but it has adapted to many other Convolvulaceae: sweet potato, Ipomoea aquatica, I. pandurata, Calystegia sepium, Pharbitis purpurea, P. cathartica, etc.

The beetle has become secondarily polyphagous, and adapted mostly in North America to corn (Zea mays), sugarbeet, tomato, and many other crops and weeds. In the tropics, so far it remains a major pest of sweet potato and related plants.

\section{Conclusion}

Few parasites have been recorded on this beetle and related species: fungi (Laboulbeniales, Beauveria), nematodes (Howardula), bacteria (Xanthomonas) and one parasitoid (Ichneumonidae). 
Except in the US, where the beetle can become a serious pest on various crops, sweet potato seems to be the only host in the tropics. Several other Chaetocnema species and other alticines are also parthenogenetic and that seems to help in the expansion of the species. Chaetocnoma confinis is invading the whole of the tropics, mainland and islands together, and is becoming the most ubiquitous chrysomelid. Exchanges between Europe and the US have been common in the past (Colorado Potato Beetle, Plagiodera and many others) but only due to passive importations. This time the beetle seems to have dispersed by wind. Strict quarantine measures are certainly necessary in places like Australia when importing sweet potatoes, but aerial dispersion is very probable in the near future.

\section{References}

Biondi M (2002) Checklist of Afrotropical species of the genus Chaetocnema Stephens (Col. Chrys.: Alticinae): synonymies and geographical distribution. Afr Entomol10:265-284

Cox ML (1996) Parthenogenesis in the Chrysomeloidea. In: Jolivet P, Cox ML (eds) Chrysomelidae biology, vol 3: General studies. SPB Academic Publishing, Amsterdam, The Netherlands, pp 133151

Jolivet P (1979) Réflexions sur l'écologie, l'origine et la distribution des chrysomélides (Col.) des îles Mascareignes, avec la description de deux espe`ces nouvelles. Bull Soc Linn Lyon 48:524-528; 48:606-608, 641-649

Jolivet P (1998) Les nouveaux envahisseurs ou les chrysomélides voyageurs (Col.).

L'Entomologiste, Paris 54:33-44

White RE (1996) A revision of the genus Chaetocnema of America, north of Mexico (Col. Chrys.). Contrib Am Entomol Inst 29:1-156 